\title{
Evaluation of sampling and analysis techniques for early detection of Limnoperna fortunei (Mytilidae) in limit areas of its distribution
}

\author{
Darrigran, $G .^{\mathrm{a} *}$, Boeger, $W^{\mathrm{b}}$, Damborenea, $C .^{\mathrm{a}}$ and Maroñas, $M .^{\mathrm{a}}$ \\ ${ }^{a}$ CONICET, Facultad de Ciencias Naturales y Museo (UNLP), \\ Paseo del Bosque sin número, 1900, La Plata, Argentina

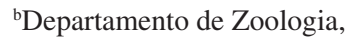 \\ Universidade Federal do Paraná - UFPR, Curitiba, PR, Brazil \\ Received October 17, 2008 - Accepted October 29, 2008 - Distributed August 31, 2009 \\ *e-mail: invasion@fcnym.unlp.edu.ar
}

The golden mussel Limnoperna fortunei (Dunker, 1857) (Mytilidae) is an invading species in continental waters in the Neotropical Region. L. fortunei is transported by human activities. Differing from fresh water bivalves native to the region, this mytilid has external fertility and a planktonic larval development similar to marine mytilids (Monteiros-Ribas et al., 2006). The impact produced by L. fortunei on numerous South American rivers includes, among others, alteration of benthonic communities, alteration of fish diet, as well as severe macrofouling problems at industrial water intakes (Darrigran, 2002). Thus, it is fundamental to know the dynamic distribution of this invading species to explain its invading process and to have access to basic information to predict its distribution/ dispersion pattern.

In the framework of a larger Project, in which we try to establish the extreme distribution limits of this species in South America, this work has as its goal to evaluate the efficiency of the sampling techniques of larvae and adults for the early detection of the invading species. For this purpose, sampling was carried out in different water bodies in limit areas of the species distribution in the endorreic system in the Province of Cordoba, Argentina.

Between December 15 and 18, 2006, quantitative and qualitative samples of benthos and plankton were taken in eight localities looking for adults and larvae of the golden mussel (Table 1). Differing from sampling techniques in environments already invaded by the golden mussel where the aim is to know the population distribution of the settlement (e.g. Mansur et al., 2003), the goal of the sampling done in this work was early detection of the invading bivalve. The presence of adults of L. fortune $i$ was determined by inspecting dredged-out submerged blocks (manually and with an Eckman type dredge) and by inspecting rocky exposures along the coast and on the riverbed. Detection of the larvae was

Table 1. Sampling stations and detection of larvae. A and B replicas of plankton samples: (1) analysis with optical microscope, (2): analysis with the molecular method; *presence of adults of the golden mussel in the environment.

\begin{tabular}{|c|c|c|c|c|c|}
\hline Date & Station & Sample & $\begin{array}{c}\text { (1) } \\
\text { Quantitative } \\
\text { larvae/L }\end{array}$ & $\begin{array}{l}\text { (1) } \\
\text { Qualitative }\end{array}$ & $\begin{array}{c}\text { (2) PCR } \\
\text { Techniques } \\
\text { Sequences }\end{array}$ \\
\hline \multirow[t]{2}{*}{$15 / 12 / 06$} & \multirow{2}{*}{$\begin{array}{l}\text { Río Carcarañá River } \\
32^{\circ} 51.221^{\prime} \mathrm{S} \text { and } 61^{\circ} 10.280^{\prime} \mathrm{W}\end{array}$} & A & $(-)$ & $(+)$ & $18 \mathrm{~S}-\mathrm{COI}$ \\
\hline & & B & 0.197 & & \\
\hline \multirow[t]{2}{*}{$16 / 12 / 06$} & \multirow{2}{*}{$\begin{array}{l}\text { *Río Tercero River in Villa María } \\
32^{\circ} 25.191^{\prime} \mathrm{S} \text { and } 63^{\circ} 15.274^{\prime} \mathrm{W}\end{array}$} & A & $(-)$ & $(+)$ & $18 \mathrm{~S}-\mathrm{COI}$ \\
\hline & & B & $(-)$ & $(-)$ & \\
\hline \multirow[t]{2}{*}{ 16/12/06 } & \multirow{2}{*}{$\begin{array}{l}\text { *Río Tercero River in Río Tercero } \\
32^{\circ} 09.350^{\prime} \mathrm{S} \text { and } 64^{\circ} 06.818^{\prime} \mathrm{W}\end{array}$} & A & $(-)$ & $(-)$ & $18 \mathrm{~S}-\mathrm{COI}$ \\
\hline & & B & $(-)$ & & \\
\hline \multirow[t]{2}{*}{$17 / 12 / 06$} & \multirow{2}{*}{$\begin{array}{l}\text { Piedras Moras Dam } \\
32^{\circ} 10.508^{\prime} \mathrm{S} \text { and } 64^{\circ} 15.119^{\prime} \mathrm{W}\end{array}$} & A & $(-)$ & $(+)$ & $18 \mathrm{~S}-\mathrm{COI}$ \\
\hline & & B & 0.063 & & \\
\hline \multirow[t]{2}{*}{ 17/12/06 } & \multirow{2}{*}{$\begin{array}{l}\text { *Río Tercero Dam } \\
32^{\circ} 11.993^{\prime} \mathrm{S} \text { and } 64^{\circ} 24.355^{\prime} \mathrm{W}\end{array}$} & A & $(-)$ & $(-)$ & $18 \mathrm{~S}-\mathrm{COI}$ \\
\hline & & B & 0.367 & & \\
\hline \multirow[t]{2}{*}{$17 / 12 / 06$} & \multirow{2}{*}{$\begin{array}{l}\text { Río Segundo River in Despeñaderos } \\
31^{\circ} 48.635^{\prime} \mathrm{S} \text { and } 64^{\circ} 17.167^{\prime} \mathrm{W}\end{array}$} & A & $(-)$ & $(+)$ & $18 \mathrm{~S}-\mathrm{COI}$ \\
\hline & & B & 0.098 & & \\
\hline \multirow[t]{2}{*}{$17 / 12 / 06$} & \multirow{2}{*}{$\begin{array}{l}\text { Los Molinos Dam } \\
31^{\circ} 49.988^{\prime} \mathrm{S} \text { and } 64^{\circ} 30.31^{\prime} \mathrm{W}\end{array}$} & A & $(-)$ & $(+)$ & $18 \mathrm{~S}-\mathrm{COI}$ \\
\hline & & B & $(-)$ & & \\
\hline \multirow[t]{2}{*}{$18 / 12 / 06$} & \multirow{2}{*}{$\begin{array}{l}\text { *San Roque Dam } \\
31^{\circ} 24.542^{\prime} \mathrm{S} \text { and } 64^{\circ} 29.62^{\prime} \mathrm{W}\end{array}$} & A & $(-)$ & $(+)$ & $18 \mathrm{~S}-\mathrm{COI}$ \\
\hline & & B & $(-)$ & $(-)$ & \\
\hline
\end{tabular}


carried out by filtering between 200 and 1,000 L through a $35 \mu \mathrm{m}$ mesh.

At each locality a sample and a replica were taken for qualitative and quantitative analysis through re-count under the optical microscope and another sample for the detection of larvae through molecular analysis according to Boeger et al. (2007).

The results through the optical microscope are presented in Table 1. According to this method, some of the localities were negative and at others, in spite of being positive in the qualitative analysis, it was not possible to obtain density values because of the scarce number of larvae present.

All the localities sampled were positive for the molecular test (Table 1). When comparing the estimated densities of larvae (between 0.197 larvae/L in the Carcaraña River and 0.098 larvae/L in the Segundo River) with those reported for the Paraná River at a similar latitude (3.64 larvae/L; 21/09/07, Timbúes; $32^{\circ} 34.571$ ' $\mathrm{S}$ and $60^{\circ} 47.199^{\prime} \mathrm{W}$, Darrigran, unpublished data), the low density of larvae detected was evident. This fact and the low frequency of adults in the sampling (Table 1) show that, on the date the samplings were done, the species was at an initial stage of invasion.

The results obtained give great accuracy for:

1) The sampling method of plankton in relation to the sampling method of benthos (the presence of adults was only detected in 4 of the 8 localities sampled);

2) The molecular technique of larvae detection related to the traditional search method under optical microscope; and

Finally, it is worth noting that from this work onwards, the distribution of the species in the centre of the Argentine Republic was enlarged in an endorreic hydrographical system in the following water bodies: Carcaraña River, Tercero River in Villa Maria, Tercero River in Rio Tercero, Piedras
Moras Dam, Segundo River in Despeñaderos, Los Molinos Dam and San Roque Dam in Carlos Paz Village. The species dispersions invading these water bodies was countercurrent and the invading system was not related to the Plata Basin. This fact shows the influence of human activity acting as a vector in the dispersion of Limnoperna fortunei in South America.

Acknowledgements - The present work was partially funded by the Committee for Research and Exploration-National Geographic Society (Grant 7824-05); the FCNyM (UNLP); the Agencia de Promoción Científica y Tecnológica (BID 1728/ OC-AR Pict 25621); CONICET (PIP 6370). We thank M. Lagreca (Comisión de Investigaciones Cientificas-CIC, Bs.As.) for technical support.

\section{References}

BOEGER, W., PIE, M., FALLEIROS, R., OSTRENSKY, A., DARRIGRAN, G., MANSUR, MC. and BELZC., 2007. Testing a molecular protocol to monitor the presence of golden mussel larvae (Limnoperna fortunei) in plankton samples. Journal of Plankton Research, vol. 29, no. 11, p. 1015-1019.

DARRIGRAN, G., 2002. Potential impact of filter-feeding invaders on temperate inland freshwater environments. Biological Invasion, vol. 4, p. 145-156.

MANSUR, MC., DOS SANTOS, CP., DARRIGRAN, G., HEYDRICH, I., CALLIL, CT. and CARDOSO, FR., 2003. Primeros dados quali-quantitativos do mexilhao-dourado, Limnoperna fortunei (Dunker), no Delta do Jacuí, no Lago Guaíba e no Laguna dos Patos, Rio Grande do Sul, Brasil e alguns aspectos de sua invasao no novo ambiente. Revista Brasileira de Zoologia, vol. 20, no. 1, p. 75-84.

MONTEIRO-RIBAS, W., OCHA-MMIRANDA, F., ROMANO, RC. and UINTANILHA, J., 2006. Larval development Brachidontes olisianus (Bivalvia, Mytilidae), with notes on differences between its hinge system and that of the mollusk Perna perna. Revista Brasileira de Biologia = Brazilian Journal of Biology, vol. 6, no. 11A, p. 109-116. 